\title{
Short communication Identification of personal risk of breast cancer: genetics
} Diana M Eccles

\begin{abstract}
Wessex Clinical Genetics Service (Southampton University Hospitals NHS Trust) and Cancer Sciences Division (University of Southampton), Princess Anne Hospital, Southampton SO16 5YA, UK
\end{abstract}

Corresponding author: Diana M Eccles, d.m.eccles@soton.ac.uk

Published: 18 December 2008

This article is online at http://breast-cancer-research.com/content/10/S4/S12

(c) 2008 BioMed Central Ltd

\section{Background}

Family history has long been recognized to be a potent risk factor for breast cancer [1]. Family histories often comprise only one or two affected relatives, who frequently were not particularly young at onset. Occasionally, a family contains a striking constellation of young-onset breast (and often other) cancers apparently transmitted as a dominant genetic trait. Over a century ago, the much referenced French neurologist Paul Broca wrote about the family of his wife, in which the occurrence of many cancers, particularly of the breast, strongly suggested the presence of a genetic predisposition [1]. It was to be more than a hundred years before the discovery of the structure of DNA and rapid advances in molecular technology would allow the first major breast cancer susceptibility gene, $B R C A 1$, to be mapped to chromosome $17 q$ [2]. In families linked to the BRCA1 locus, a much younger age at onset than average and the frequent occurrence of ovarian cancers were noted to be typical. At about the same time, the cause of a rare but devastating familial cancer syndrome was identified; mutations in the TP53 gene had also been found to account for the very rare Li Fraumeni syndrome associated with very young onset breast cancers and childhood malignancy, particularly soft tissue sarcomas $[3,4]$.

A second major breast cancer susceptibility gene, BRCA2, was mapped to chromosome $13 q$ in 1994 shortly before the sequence of the BRCA1 gene was clarified and familyspecific disease-causing mutations started to be reported $[5,6]$. The full BRCA2 gene sequence was reported in 1995 [7]. Families with mutations in the BRCA2 gene were noted to be more likely to contain a male breast cancer case than might be expected by chance (and more than had been seen in families due to BRCA1 mutations); ovarian and fallopian tube cancers still occurred with increased frequency but overall not as frequently as in BRCA1-associated families. With the discovery of the correct gene sequences for $B R C A 1$ and BRCA2 it became possible to offer predictive genetic testing to members of families in which the causative gene mutation had been identified. Predictive testing for breast cancer susceptibility was introduced as a clinical
Breast Cancer Research 2008, 10(Suppl 4):S12 (doi:10.1186/bcr2172)

service from the mid-1990s in some centres in the UK [8]. Families in which mutations were identified through research studies were the first to be informed [9]. Many of these families had been identified because of their high incidence of cancer, and so inevitably the estimated lifetime chance that a carrier of one of these genes would develop cancer was high $[10,11]$.

The BRCA1 and BRCA2 genes are very large, and mutation testing was either very expensive (in the USA) or very slow (in European countries) when it first became available. It soon became clear that mutations in these genes accounted for a relatively small proportion of all families with breast cancer clusters. Families with four or more cancer cases developing at young age, particularly those families in which ovarian cancers occurred, were more likely to yield pathogenic mutations when DNA from a cancer-affected family member was screened for mutations. Smaller clusters of later onset cancers, although clearly familial, were noted to have a much lower probability of harbouring a $B R C A 1$ or $B R C A 2$ mutation [12].

In the presence of a $B R C A 1$ or $B R C A 2$ mutation, the lifetime risk for developing breast cancer may be as high as $80 \%$ to $90 \%$, although other genes and lifestyle factors may reduce the lifetime risk to levels as low as $26 \%$. Ovarian cancer risk in BRCA1 gene carriers is estimated at about $50 \%$, but again this risk is likely to be modified by both genetic and other risk factors. For $B R C A 2$, ovarian cancer risk is about $15 \%$, but all these average risks are likely to be modified by context [13].

\section{Other breast cancer susceptibility genes}

During the past decade, no other highly penetrant breast cancer susceptibility genes like BRCA1 and BRCA2 have emerged, despite huge efforts using linkage-based studies in large breast cancer familial clusters. A variety of candidate genes were investigated and evidence presented of their involvement in breast cancer susceptibility but with much lower associated risks than for BRCA1 and BRCA2 [14-17]. It was realized that it was likely that there were no more high penetrance genes to be discovered, and that much of the 
remaining familial risk would be due to common variants in multiple genes, each conferring only very small increases in lifetime breast cancer risk [18]. As techniques for genotyping common variants (polymorphisms) across the entire genome became more economically viable, large cohorts of breast cancer patients (cases) and unaffected individuals (controls) were evaluated in genome-wide association studies [19]. Recently, these led to the discovery of several genetic variants, common in the general population, that confer an increase in lifetime breast cancer risk with odds ratios (compared with the population average) of the order of 1.3 [20-22].

Risk assessment using these genetic variants with much lower penetrance presents an interesting challenge for the future. Incorporating the seven main risk alleles of the low penetrance type discovered through genome-wide association studies, it is clear that not only would it be a very rare occurrence to carry all seven high risk alleles, but also the lifetime risks conferred are modest at best even in the presence of all seven alleles [23]. Incorporation of the effect of these common variants into risk prediction algorithms that take other known epidemiological risk factors into account does not result in a major improvement in risk prediction (at least hypothetically) [24]. The nature of the case-control cohorts thus far studied inevitably leads to findings that are more likely to apply to oestrogen receptor positive breast cancers, because these are the more frequent type of breast cancer overall. This may mean that a group identified as being at risk on the basis of today's single nucleotide polymorphisms could benefit more from intervention with a chemopreventive option such as tamoxifen [25]. However, variants that alter the rate of metabolism of tamoxifen could prevent any benefit in a proportion of the population [26].

Where risks conferred by a single gene mutation (penetrance) is high and inheritance is clear (usually autosomal dominant), the use of genetic testing in risk prediction and risk management are relatively straightforward. This is the case for BRCA1 and BRCA2 gene mutations, although risks are still clearly affected by low penetrance genetic variants as well as lifestyle factors [27-29].

In conclusion, testing of multiple single nucleotide polymorphisms to predict lifetime risk of breast cancer is not clinically valuable for an individual at present. However, over the coming decade, as most breast cancer risk associated genetic variants are identified and a clearer picture of genegene and gene-environment interactions emerges, it is likely that genetic profiles may help to guide selection of women for earlier mammographic screening and for targeted riskreducing strategies, potentially including chemoprevention or lifestyle changes (for example, weight control, earlier childbearing and longer breast feeding). Whether enough women will be prepared to change their lifestyle radically and from a young age in order to ameliorate predicted breast cancer risk remains to be seen.

\section{Competing interests}

The author declares that they have no competing interests.

\section{Acknowledgements}

This article has been published as part of Breast Cancer Research Volume 10 Supplement 4, 2008: Controversies in Breast Cancer 2008. The full contents of the supplement are available online at http://breast-cancer-research.com/supplements/10/S4

\section{References}

1. Steel M, Thompson A, Clayton J: Genetic aspects of breast cancer. Br Med Bull 1991, 47:504-518.

2. Hall JM, Lee MK, Newman B, Morrow JE, Anderson LA, Huey B, King MC: Linkage of early-onset familial breast cancer to chromosome 17q21. Science 1990, 250:1684-1689.

3. Malkin D, Li FP, Strong LC, Fraumeni JF Jr, Nelson CE, Kim DH, Kassel J, Gryka MA, Bischoff FZ, Tainsky MA, et al:: Germ line p53 mutations in a familial syndrome of breast cancer, sarcomas, and other neoplasms. Science 1990, 250:1233-1238.

4. Olivier M, Goldgar DE, Sodha N, Ohgaki H, Kleihues P, Hainaut $P$, Eeles RA: Li-Fraumeni and related syndromes: correlation between tumor type, family structure, and TP53 genotype. Cancer Res 2003, 63:6643-6650.

5. Miki Y, Swensen J, Shattuck-Eidens D, Futreal PA, Harshman K Tavtigian S, Liu Q, Cochran C, Bennett LM, Ding W, et al.: A strong candidate for the breast and ovarian cancer susceptibility gene BRCA1. Science 1994, 266:66-71.

6. Wooster R, Neuhausen SL, Mangion J, Quirk Y, Ford D, Collins N, Nguyen K, Seal S, Tran T, Averill D, et al.: Localization of a breast cancer susceptibility gene, BRCA2, to chromosome 13q12-13. Science 1994, 265:2088-2090.

7. Wooster R, Bignell G, Lancaster J, Swift S, Seal S, Mangion J Collins N, Gregory S, Gumbs C, Micklem G, Barfoot R, Hamoudi R, Patel S, Rices C, Biggs P, Hashim Y, Smith A, Connor F, Arason A, Gudmundsson J, Ficenec D, Kelsell D, FordTonin DP, Bishop DT, Spurr NK, Ponder BA, Eeles R, Peto J, Devilee P, Cornelisse $C$, et al.: Identification of the breast cancer susceptibility gene BRCA2. Nature 1995, 378:789-792.

8. Working group for the Chief Medical Officer: Genetics and Cancer Services. Report of a Working Group for the Chief Medical Officer. London, UK: Department of Health; 1998.

9. Eccles DM, Englefield P, Soulby MA, Campbell IG: BRCA1 mutations in southern England. Br J Cancer 1998, 77:2199-2203.

10. Easton DF, Bishop DT, Ford D, Crockford GP: Genetic linkage analysis in familial breast and ovarian cancer: results from 214 families. The Breast Cancer Linkage Consortium. Am J Hum Genet 1993, 52:678-701.

11. Ford D, Easton DF, Stratton M, Narod S, Goldgar D, Devilee $P$, Bishop DT, Weber B, Lenoir G, Chang-Claude J, Sobol H, Teare MD, Struewing J, Arason A, Scherneck S, Peto J, Rebbeck TR, Tonin P, Neuhausen S, Barkardottir R, Eyfjord J, Lynch H, Ponder BA, Gayther SA, Zelada-Hedman M, et al:: Genetic heterogeneity and penetrance analysis of the BRCA1 and BRCA2 genes in breast cancer families. The Breast Cancer Linkage Consortium. Am J Hum Genet 1998, 62:676-689.

12. Bishop DT: BRCA1 and BRCA2 and breast cancer incidence: a review. Ann Oncol 1999, 10(suppl):S113-S119.

13. Antoniou A, Pharoah PD, Narod S, Risch HA, Eyfjord JE, Hopper $\mathrm{JL}$, Loman N, Olsson H, Johannsson O, Borg A, Pasini B, Radice $\mathrm{P}$, Manoukian S, Eccles DM, Tang N, Olah E, Anton-Culver H, Warner E, Lubinski J, Gronwald J, Gorski B, Tulinius H, Thorlacius S, Eerola H, Nevanlinna H, Syrjäkoski K, Kallioniemi OP, Thompson D, Evans C, Peto J, et al:: Average risks of breast and ovarian cancer associated with BRCA1 or BRCA2 mutations detected in case series unselected for family history: a combined analysis of 22 studies. Am J Hum Genet 2003, 72:11171130.

14. Weischer M, Bojesen SE, Tybjaerg-Hansen A, Axelsson CK, Nordestgaard BG: Increased risk of breast cancer associated with CHEK2*1100delC. J Clin Oncol 2007, 25:57-63.

15. Renwick A, Thompson $D$, Seal $S$, Kelly $P$, Chagtai $T$, Ahmed $M$, North B, Jayatilake H, Barfoot R, Spanova K, McGuffog L, Evans DG, Eccles D; Breast Cancer Susceptibility Collaboration (UK), Easton DF, Stratton MR, Rahman N: ATM mutations that cause 
ataxia-telangiectasia are breast cancer susceptibility alleles. Nat Genet 2006, 38:873-875.

16. Rahman N, Seal S, Thompson D, Kelly P, Renwick A, Elliott A, Reid S, Spanova K, Barfoot R, Chagtai T, Jayatilake H, McGuffog L, Hanks S, Evans DG, Eccles D; Breast Cancer Susceptibility Collaboration (UK), Easton DF, Stratton MR: PALB2, which encodes a BRCA2-interacting protein, is a breast cancer susceptibility gene. Nat Genet 2007, 39:165-167.

17. Seal S, Thompson D, Renwick A, Elliott A, Kelly P, Barfoot R, Chagtai T, Jayatilake H, Ahmed M, Spanova K, North B, McGuffog L, Evans DG, Eccles D; Breast Cancer Susceptibility Collaboration (UK), Easton DF, Stratton MR, Rahman N: Truncating mutations in the Fanconi anemia J gene BRIP1 are low-penetrance breast cancer susceptibility alleles. Nat Genet 2006, 38:12391241.

18. Pharoah PD, Antoniou A, Bobrow M, Zimmern RL, Easton DF, Ponder BA: Polygenic susceptibility to breast cancer and implications for prevention. Nat Genet 2002, 31:33-36.

19. Pharoah PD, Dunning AM, Ponder BA, Easton DF: Association studies for finding cancer-susceptibility genetic variants. Nat Rev Cancer 2004, 4:850-860.

20. Easton DF, Pooley KA, Dunning AM, Pharoah PD, Thompson D, Ballinger DG, Struewing JP, Morrison J, Field H, Luben R, Wareham N, Ahmed S, Healey CS, Bowman R; SEARCH collaborators, Meyer KB, Haiman CA, Kolonel LK, Henderson BE, Le Marchand L, Brennan P, Sangrajrang S, Gaborieau V, Odefrey F, Shen CY, Wu PE, Wang HC, Eccles D, Evans DG, Peto J, Fletcher $\mathrm{O}$, et al:: Genome-wide association study identifies novel breast cancer susceptibility loci. Nature 2007, 447:10871093.

21. Hunter DJ, Kraft P, Jacobs KB, Cox DG, Yeager M, Hankinson SE, Wacholder S, Wang Z, Welch R, Hutchinson A, Wang J, Yu K, Chatteriee N, Orr N, Willett WC, Colditz GA, Ziegler RG, Berg $\mathrm{CD}$, Buys SS, McCarty CA, Feigelson HS, Calle EE, Thun MJ, Hayes RB, Tucker M, Gerhard DS, Fraumeni JF Jr, Hoover RN, Thomas G, Chanock SJ: A genome-wide association study identifies alleles in FGFR2 associated with risk of sporadic postmenopausal breast cancer. Nat Genet 2007, 39:870-874.

22. Stacey SN, Manolescu A, Sulem P, Thorlacius S, Gudjonsson SA Jonsson GF, Jakobsdottir M, Bergthorsson JT, Gudmundsson J, Aben KK, Strobbe LJ, Swinkels DW, van Engelenburg KC, Henderson BE, Kolonel LN, Le Marchand L, Millastre E, Andres R, Saez B, Lambea J, Godino J, Polo E, Tres A, Picelli S, Rantala J, Margolin S, Jonsson T, Sigurdsson H, Jonsdottir T, Hrafnkelsson J, et al:: Common variants on chromosome $5 \mathrm{p} 12$ confer susceptibility to estrogen receptor-positive breast cancer. Nat Genet 2008, 40:703-706.

23. Pharoah PD, Antoniou AC, Easton DF, Ponder BA: Polygenes, risk prediction, and targeted prevention of breast cancer. $N$ Engl J Med 2008, 358:2796-2803.

24. Gail MH: Discriminatory accuracy from single-nucleotide polymorphisms in models to predict breast cancer risk. $J$ Natl Cancer Inst 2008, 100:1037-1041.

25. Cuzick J, Forbes JF, Sestak I, Cawthorn S, Hamed H, Holli K, Howell A; International Breast Cancer Intervention Study I Investigators: Long-term results of tamoxifen prophylaxis for breast cancer-96-month follow-up of the randomized IBIS-I trial. J Natl Cancer Inst 2007, 99:272-282.

26. Schroth W, Antoniadou L, Fritz P, Schwab M, Muerdter T, Zanger UM, Simon W, Eichelbaum M, Brauch H: Breast cancer treatment outcome with adjuvant tamoxifen relative to patient CYP2D6 and CYP2C19 genotypes. J Clin Oncol 2007, 25: 5187-5193.

27. Antoniou AC, Spurdle AB, Sinilnikova OM, Healey S, Pooley KA, Schmutzler RK, Versmold B, Engel C, Meindl A, Arnold N, Hofmann W, Sutter C, Niederacher D, Deissler H, Caldes T, Kämpjärvi K, Nevanlinna H, Simard J, Beesley J, Chen X; Kathleen Cuningham Consortium for Research into Familial Breast Cancer, Neuhausen SL, Rebbeck TR, Wagner T, Lynch HT, Isaacs C, Weitzel J, Ganz PA, Daly MB, Tomlinson G, et al:: Common breast cancer-predisposition alleles are associated with breast cancer risk in BRCA1 and BRCA2 mutation carriers. Am $J$ Hum Genet 2008, 82:937-948.

28. Andrieu N, Goldgar DE, Easton DF, Rookus M, Brohet R, Antoniou AC, Peock $S$, Evans $G$, Eccles $D$, Douglas $F$, Noguès $C$, Gauthier-Villars M, Chompret A, Van Leeuwen FE, Kluijt I, Benitez $\mathrm{J}$, Arver B, Olah E, Chang-Claude J; EMBRACE; GENEPSO;
GEO-HEBON; IBCCS Collaborators Group: Pregnancies, breast-feeding, and breast cancer risk in the International BRCA1/2 Carrier Cohort Study (IBCCS). J Natl Cancer Inst 2006, 98:535-544.

29. Andrieu N, Easton DF, Chang-Claude J, Rookus MA, Brohet R, Cardis E, Antoniou AC, Wagner T, Simard J, Evans G, Peock S, Fricker JP, Nogues C, Van't Veer L, Van Leeuwen FE, Goldgar $D E$ : Effect of chest X-rays on the risk of breast cancer among BRCA1/2 mutation carriers in the International BRCA1/2 Carrier Cohort Study: a report from the EMBRACE, GENEPSO, GEO-HEBON, and IBCCS Collaborators' Group. J Clin Oncol 2006, 24:3361-3366. 